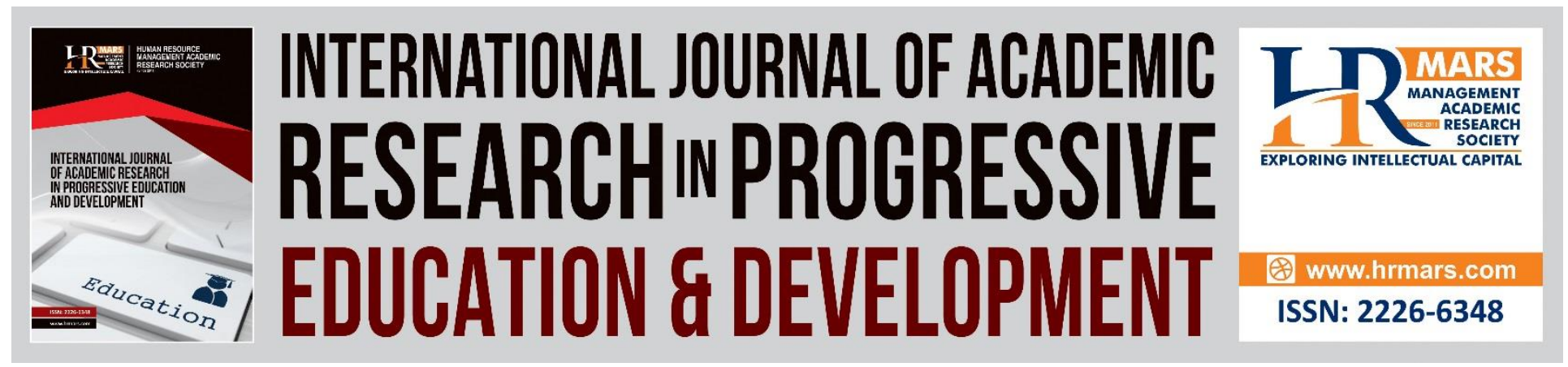

\title{
Socio-Demographic Analysis of Pupils Involvement in Negative Activities
}

\section{Mohd Mahzan Awang, Abdul Razaq Ahmad, Mohd Salim Awang}

To Link this Article: http://dx.doi.org/10.6007/IJARPED/v10-i1/8719

DOI:10.6007/IJARPED/v10-i1/8719

Received: 10 January 2021, Revised: 06 February 2021, Accepted: 27 February 2021

Published Online: 20 March 2021

In-Text Citation: (Awang et al., 2021)

To Cite this Article: Awang, M. M., Ahmad, A. R., \& Awang, M. S. (2021). Socio-Demographic Analysis of Pupils Involvement in Negative Activities. International Journal of Academic Research in Business and Social Sciences, 10(1), 304-310.

Copyright: (C) 2021 The Author(s)

Published by Human Resource Management Academic Research Society (www.hrmars.com)

This article is published under the Creative Commons Attribution (CC BY 4.0) license. Anyone may reproduce, distribute, translate and create derivative works of this article (for both commercial and non-commercial purposes), subject to full attribution to the original publication and authors. The full terms of this license may be seen at: http://creativecommons.org/licences/by/4.0/legalcode

Vol. 10(1) 2021, Pg. 304 - 310

Full Terms \& Conditions of access and use can be found at http://hrmars.com/index.php/pages/detail/publication-ethics 


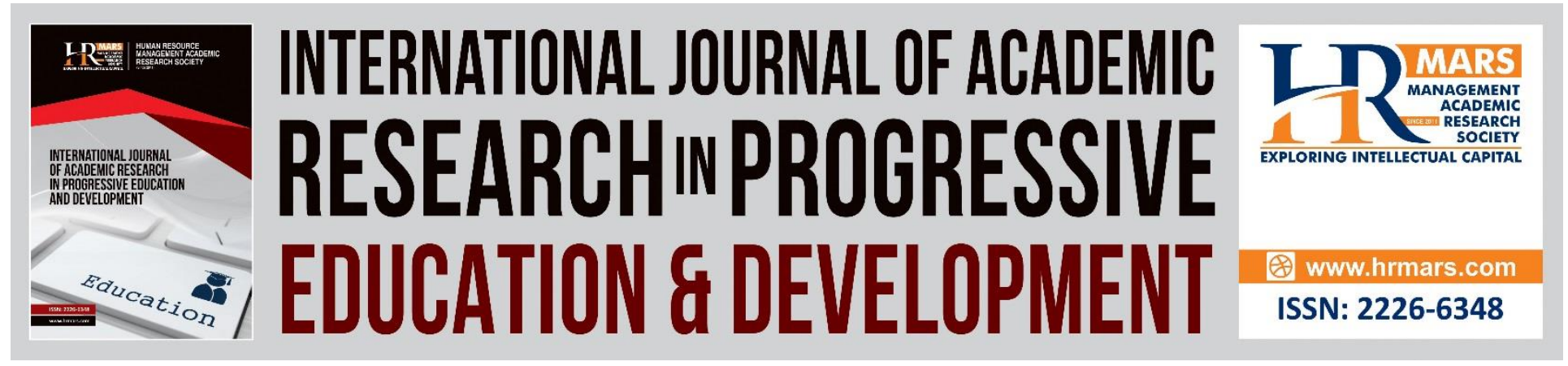

\title{
Socio-Demographic Analysis of Pupils Involvement in Negative Activities
}

\author{
Mohd Mahzan Awang, Abdul Razaq Ahmad \\ Faculty of Education, The National University of Malayia \\ Email: mahzan@ukm.edu.my,razaq@ukm.edu.my
}

\author{
Mohd Salim Awang \\ Institute of Aminuddin Baki, Malaysia \\ Email: salim_awang@yahoo.com
}

\begin{abstract}
This paper presents data from self-declared behaviour of pupils' involvement in negative activities that are often occurred in Malaysian urban secondary schools that are pupils' involvement in skipping classes, smoking cigarette, bullying, cheating in exams and vandalising properties. This study used a survey research design to investigate pupils' involvement in acclivities. A set of questionnaire was used to collect data from 15 urban schools in Malaysia. Results from this study revealed that cheating and truancy are the often problem behaviour exhibited in schools. Result also found that more boys involved in negative activities compared to girls. Socio-demographic analyses demonstrated that pupils from low-academic families are more likely to involve in negative activities compact to others. Results also found that more Malay reported to involve in negative activities compared to other ethnicities. Overall finding suggests that pupils may not see their involvement in such activities as problematic. It can be argued they may have different perceptions regarding the seriousness level of such activities.

Keywords: Negative Behaviour, Socio-Demographic, Pupils, School, Truancy, Smoking

\section{Introduction}

Behavioural problems and involvement of pupils in negative activities pose challenges to many school professionals worldwide. It has been reported that the increasing numbers on behavioural issues are associated in socio-ecological environments including family backgrounds, gander aspects and social networkings. In a school context, challenging behaviour exhibited by pupils is coded to be disciplinary issue (Ehiane, 2014). It poses a challenge in teaching profession in schools. It is important $t$ study pupils' involvement in negative activities as it provides useful data for intervention strategies. One of the ways to know about pupils' involvement in negative activities is to use a self-declared form for pupils.
\end{abstract}




\section{Negative Activities and Behavioural Problems}

Statistical reports show that 10,154 disciplinary issues occurred in Malaysia (Rahim 2019). Of these, truancy was the most frequent problem occurred in schools. It has been reported that a number 20 pupils had been expelled from a school after they were found guilty of being involved in gangster activities. In February 2009, a 16-year-old Malaysian pupil died after he was beaten by a group of pupils (Suffian, 2009). The Social Welfare Department of Malaysia reported that a total number of 5,319 youths were engaged in juvenile cases in 2002 (Yahaya, Geog \& Abdul 2004). Teachers from a southern region of Malaysia reported that pupils were often involved in unacceptable activities such as truancy, stealing, and gang fighting (Yahaya et al., 2009). Similar problems also occurr in other countries. For instance, Learner (2008) reported that more than 4,000 children in the United Kingdom were suspended from school due to physical assault, verbal abuse, bullying behaviour, sexual abuse, sexual misconduct, drug trafficking and alcohol-related problems. In the USA, the 2006 national survey reported that $82 \%$ of American youth admitted they lied to their parents, $62 \%$ said they lied to a teacher, $60 \%$ reported they cheated in a test at school, and $20 \%$ stated that they stole something from a store (Lumpkin, 2008).

\section{Purpose of the Study}

The current study aims at:

- identifying the levels of pupils' involvement in negative activities in terms-of their involvement in skipping classes, smoking cigarette, bullying, cheating in exams and vandalising properties, and

- analysing the the pupils' involvement in skipping classes, smoking cigarette, bullying, cheating in exams and vandalising propertie based on socio-demographic backgrounds.

\section{Methodology}

This study used a survey research design to investigate pupils' involvement in activities. A set of questionnaire was used to collect data from 15 urban schools in Malaysia. The questionnaire contains a fixed-response where the respondents were asked to state his/her involvement in predetermined five negative activities i.e. skip classes, smoking habits, bullying, cheating and vandalism. Missing data was coded as no response. Respondents in this study were randomly selected. They were asked to declare their experiences of those situations. Response options were: 1 =yes; 2 = no; or 3 = choose not to tell. A descriptive analysis was calculated on the pupil data.

\section{Results and Discussion}

A total number of 494 multi-ethnic Form 4 (aged 16 years) school pupils were respondents in this study. In this study, more girls $(54 \%, n=269)$ than boys $(46 \%, n=265)$ involved, and that the majority were Malay $(52 \%, n=256)$, followed by Chinese $(26 \%, n=126)$ and Indian $(20 \%, n=99)$. As depicted in Table 1, most pupils reported that they did not participate in these negative activities. For instance, $59 \%$ of pupils ( $n=291$ ) reported that they never missed a class without permission. Only $5 \%(n=22)$ of pupils reported they have smoked outside of school, but this does not mean that they have never smoked within the school compound. A small percentage of pupils (17\%, $\mathrm{n}=84$ ) reported that they had vandalised school property. 
Table 1. Pupils' statement regarding their involvement in negative activities

\begin{tabular}{l|c|c|c}
\hline \multicolumn{1}{c|}{ Negative Activities } & Yes & No & $\begin{array}{c}\text { Choose not to } \\
\text { tell }\end{array}$ \\
\hline $\begin{array}{l}\text { I have never missed a class without } \\
\text { the teacher's or my parent's } \\
\text { permission. }\end{array}$ & $\begin{array}{c}59 \% \\
(n=291)\end{array}$ & $\begin{array}{c}27 \% \\
(n=131)\end{array}$ & $14 \%(n=67)$ \\
I smoke outside of school. & $\begin{array}{c}5 \% \\
(n=22)\end{array}$ & $\begin{array}{c}91 \% \\
(n=451)\end{array}$ & $4 \%(n=18)$ \\
Pupils in this school have bullied me. & $\begin{array}{c}14 \% \\
(n=71)\end{array}$ & $\begin{array}{c}79 \% \\
(n=389)\end{array}$ & $6 \%(n=31)$ \\
I have cheated in a school test. & $\begin{array}{c}37 \% \\
(n=185)\end{array}$ & $\begin{array}{c}42 \% \\
(n=209)\end{array}$ & $19 \%(n=96)$ \\
I have vandalised school property. & $\begin{array}{c}17 \% \\
(n=84)\end{array}$ & $\begin{array}{c}75 \% \\
(n=371)\end{array}$ & $7 \%(n=36)$ \\
\hline
\end{tabular}

One-third of this cohort reported that they had cheated in a school test (37\%, $n=185)$. This might have a link with an overemphasis on academic achievements rather than holistic achievement in both academic and non-academic aspects. However, there was insufficient narrative data to provide a further explanation regarding this finding, and thus future research is needed.

These results indicate that two situations require prompt action: cheating in school tests and victimisation in school. A total of 185 pupils reported that they had cheated in exams and 71 pupils reported that they had been bullied. However, the forms of bullying are undefined, and it is unknown whether schools realise the extent of this problem. Cheating is a serious ethical issue in academics, therefore creating positive learning environment to promote positive engagement among learners is really needed (Goss, Sonnemann and Griffiths 2017). These issues should be addressed in future studies. The next subsection presents a detailed analysis of problem behaviour identified in this study.

\section{Socio-Demographic Analyses of Pupils' Involvement in Negative Activities Absenteeism}

The response of "no" (see Table 1) was interpreted as "pupils have missed a class without permission" in this analysis. Thus, $27 \%(n=131)$ of pupils had missed a class without permission. These 131 pupils, 57\% ( $n=75)$ were boys and the majority were Malay (59\%, $n=77)$. Pupils from families where both parents had certificate level education $(42 \%, n=55)$ were more likely to skip a class than pupils from other family backgrounds (Table 5.35 ). 
Vol. 10, No. 1, 2021, E-ISSN: 2226-6348 @ 2021 HRMARS

Table 2. Pupils who reported they had missed a class without permission

\begin{tabular}{llcc}
\hline \multicolumn{1}{c}{ Variables } & $\%$ & $n$ \\
\hline \multirow{2}{*}{ Gender } & Boys & 57 & 75 \\
& Girls & 43 & 56 \\
\hline & Both parents had a master's degree or & & \\
& PhD & 2 & 3 \\
& Both parents had a bachelor's degree & 2 & 2 \\
& Both parents had a diploma & 5 & 6 \\
& Both parents had a certificate & 42 & 55 \\
Parents' academic & Both parents had no specific & & \\
backgrounds & qualifications & 2 & 3 \\
& One parent had a master's degree or & & \\
& PhD & 7 & 9 \\
& One parent had a bachelor's degree & 4 & 5 \\
& One parent had a diploma & 5 & 6 \\
& One parent had a certificate & 5 & 6 \\
\hline Total & No response & 27 & 36 \\
\hline
\end{tabular}

\section{Smoking Habits}

Of 22 pupils who reported they smoked, the majority were boys $(73 \%, n=16)$ and over half were Malay $(68 \%, n=15)$. Thirty-two per cent of smokers $(n=7)$ were from families where both parents had certificate level education. This is alarming as it has been reported that over 1.1 billion people smoked cigarettes and the number of smokers increasing globally (World Health Organization 2017). Smoking is proven scientifically dangerous and leading causes of death. World Health Organization (2017) reported that each year, around six million people die as a direct result of smoking. Health problems and illness related to smoking habits are cancer, cardiovascular problems, respiratory problems and stroke. The current finding highlights the importance of preventive measures of smoking habit among pupils (Hasim 2000).

\section{Bullying}

The findings from this study revealed that of 71 who reported they had been bullied, $15 \%$ were boys $(n=34)$ and $14 \%$ were girls $(n=37)$. Indian $(24 \%, n=24)$ were more likely to report being bullied than other ethnic groups ( $n=2$; Malay, 11\%, $n=29$; Chinese, $n=16)$. Bullying behaviour includes teasing, taunting, threatening, physically attacking and isolating other pupils through intentional exclusion (Harel-Fisch, et al., 2011; Pugh and Chitiyo, 2011). The occurrence of bullying in a school context is still existed regardless of anti-bullying efforts internationally.

\section{Cheating}

A higher percentage of boys $(87 \%, n=47)$ than girls $(53 \%, n=98)$ said they had cheated in a school test, and most of these were Malay $(57 \%, n=105)$. Over half of pupils from families where parents 
Vol. 10, No. 1, 2021, E-ISSN: 2226-6348 @ 2021 HRMARS

had a certificate level of education said that they had cheated in a school test $(42 \%, n=77)$. This informs the importance of behavioural intervention in schools (Sørlie and Ogden 2014)

Table 5.36 Pupils who reported cheating in a school test

\begin{tabular}{llcc}
\hline & \multicolumn{1}{c}{ Variables } & $\%$ & $n$ \\
\hline \multirow{2}{*}{ Gender } & Boys & 47 & 87 \\
& Girls & 53 & 98 \\
\hline & Both parents had a master's degree or & 3 & 5 \\
& PhD & 1 & 2 \\
& Both parents had a bachelor's degree & 5 & 9 \\
& Both parents had a diploma \\
& Both parents had a certificate & 72 & 77 \\
Parental academic & $\begin{array}{l}\text { Both parents had no specific } \\
\text { backgrounds }\end{array}$ & 42 & 6 \\
& $\begin{array}{l}\text { One parent had a master's degree or } \\
\text { PhD }\end{array}$ & 3 & 10 \\
& One parent had a bachelor's degree & 5 & 9 \\
& One parent had a diploma & 5 & 11 \\
& One parent had a certificate & 6 & 9 \\
Notal & No response & 5 & 47 \\
\hline
\end{tabular}

\section{Vandalism}

Most pupils who said they had vandalised school property were boys $(n=45)$, and many were from families where both the parents had certificate level education ( $n=29)$. In terms of ethnicity, 50 were Malay, followed by Chinese $(n=8)$ and Indian $(n=3)$. Kambuga (2017) reported that a comprehensive strategy is needed to prevent vandalism activities.

\section{Conclusion}

Results from the survey of self-declared behaviour in this study demonstrated that boys were more likely to report that they engaged in more challenging behaviour than girls did. Most pupils who said that they had been involved in negative activities were from families with a low level of academic achievement. Self-reporting of involvement in negative behaviour suggests that pupils may not see their involvement in such activities as problematic. Further, it can be argued they may have different perceptions regarding the seriousness level of such activities. The current study implies that investigating pupils behavioural problems can be carried out by using a confession-based survey including the use of self-declared behaviour. It is important consider this technique as pupils who involved in negative activities would like to tell others. Indeed, they may be proud of breaching the school rules. The current study also implies the importance of socio-demographic factors while planning intervention strategies to avoid pupils' involvement in negative activities. The current study also highlights the important of specific strategies by taking 
into account socio-demographic factors to prevent and intervene pupils' involvement in negative activities.

\section{Acknowledgement}

Data presented in this paper was based on a large scale of doctoral research data carried out by the first author. Appreciation to Faculty of Education, The National University of Malaysia for supporting this publication (Code: K016391).

\section{References}

Ehiane, O. S. (2014). Discipline and academic performance: A Study of selected secondary schools in Lagos, Nigeria. International Journal of Academic Research in Progressive Education and Development, 3(1), 181-194.

Goss, P., Sonnemann, J., \& Griffiths, K. (2017). Engaging students: Creating classrooms that improve learning. Melbourne, Australia: Grattam Institute.

Hasim, T. J. (2000) Smoking habits of students in College of Applied Medical Science, Saudi

Arabia. Saudi Medical Journal, 21(1),76-80.

Kambuga, Y. (2017). The challenge of managing pupils' discipline in Tanzanian schools. Journal of Administrative Management, Education and Training, 13(2), 25-33.

Learner, S. (2008, 6th of November). Thousands of Primary School Children Suspended. Children and Young People Now Bulletin.

Lumpkin, A. (2008). Teachers as Role Models: Teaching Character and Moral Virtues. Journal of Physical Education, Recreation and Dance, 79(2), 45-49.

Rahim, R. N. R. (2019). 10,154 kes disiplin babit pelajar tahun lalu [10,154 student disciplinary cases reported last year]. Berita Harian. https://www.bharian.com.my/berita/wilayah/2019/02/532222/10154-kes-disiplinbabit-pelajar-tahun-lalu

Sørlie, M-A., \& Ogden, T. (2014). Reducing threats to validity by design in a nonrandomized experiment of a school-wide prevention model. International Journal of School \& Educational Psychology, 2(4), 235-246.

http://dx.doi.org/10.1080/21683603.2014.881309

Suffian, A. B. (2009). Do Not Let a Gang Culture Activities Spread, Utusan Malaysia.

World Health Organization [WHO]. (2017). Prevalence of tobacco smoking. Retrieved July 1, 2020 from https://www.who.int/gho/tobacco/use/en/

Yahaya, A., Geok, Y. K., and Abdul, A. H. (2004). The Effectiveness of Henry Gurney School and Tunas Bakti School Programmes Paper presented at the International Seminar on Values in Community in Pasca-modenisme (SIVIC), Langkawi, Malaysia.

Yahaya, A., Ramli, J., Boon, Y., Ghafar, M. N. A., and Zakariya, Z. (2009). Relationship between Self Concepts and Personality and Students' Academic Performance in Selected Secondary. European Journal of Social Sciences, 11(2), 302-316. 